\title{
The Relative Influence of Diseases and Other Small-Scale Disturbances on Fuel Loading in the Black Hills
}

\author{
J. E. Lundquist, USDA Forest Service, Rocky Mountain Research Station, 240 West Prospect Rd., Fort Collins, CO, \\ USA 80526
}

\begin{abstract}
Lundquist, J. E. 2007. The relative influence of diseases and other small-scale disturbances on fuel loading in the Black Hills. Plant Dis. 91:147-152.

Disturbances that kill trees in forests often co-occur in time and/or space. This process results in changes in the fuel loading for wildfire. Determining specific causes of changing fuel loads can be complex. Path analysis was used to estimate the relative importance and the strength of interaction of each of nine small-scale disturbances affecting forest stands in the Black Hills. Different disturbances were partitioned according to their indirect and direct effects on fuel loads. Fire and wind had the greatest indirect effects; stem rots had the smallest. Root rots had the largest direct effects. Root rots, strong wind, stem rots, suppression, human disturbances, and tree cutting all caused fuel loads to increase. Treeless meadows, stem cankers, fire, ice/snow damage, failed regeneration, and shallow soil were associated with decreasing fuel loads. Grazing, lightning, bark beetles, and competition had null impacts. Disease control has two aims: reducing fire hazard and enhancing restoration. Understanding the biology and ecology of the agents that create dead wood is as fundamental to restoration ecology as it is to forest pathology. Management and control both begin by first determining the cause.
\end{abstract}

Additional keywords: abiotic disturbances, disturbance/fire interactions, forest disease, fuelgenerating disturbances, harvesting, insects, pathogens, surface fuels

Diseases, insects, and other small-scale disturbance agents generate fuels by creating dead snags, stunting trees, deforming branches and stems, creating resin-filled stem and branch cankers, influencing spatial continuity of fuels, increasing aggregated accumulations of fuel, diversifying canopy structure within and among stands, influencing the nature and rate of fuel decomposition, and other actions that influence the spread, intensity, and severity of wildfires. Fuels are one factor influencing fire hazard that forest managers can control (15). In a sense, however, fuels are only symptoms, and managing symptoms is only an indirect way of curing an unhealthy, risky, or hazardous condition. Understanding cause can lead to more thorough and long-term management solutions. The effects of different types of fuels on fire behavior have been fairly wellstudied, but little is known about the connections between different types of fuelgenerating disturbances and different types of fuels.

Corresponding author: J. E. Lundquist

E-mail: jlundquist@fs.fed.us

Accepted for publication 29 August 2006.

DOI: 10.1094/PDIS-91-2-0147

This article is in the public domain and not copyrightable. It may be freely reprinted with customary crediting of the source. The American Phytopathological Society, 2007.
Different disturbances vary in their qualitative and quantitative contributions to fuels. Forest diseases, in particular, are part of an assemblage of disturbance agents acting concurrently and sequentially in the ecosystem (19). Most studies of the impacts of forest pathogens have addressed single-agent interactions, but the actual impacts of specific diseases can depend on their interactions with other diseases, insects, fires, stand structure composition, site quality, drought, management history, and other biotic and abiotic factors. Indirect interactions commonly couple these agents into a web of interaction that is an essential feature of forest ecosystems. Interaction theory has become a major subject of study during the last 25 years (4). Ecologists, for example, have described the relationship among the diversity of interacting organisms and various ecosystem qualities (27), and have speculated about how this relationship impacts ecosystem stability and sustainability (8). Nonetheless, Kareiva and Wennergren (14) criticize ecologists for overemphasizing pair-wise interactions. Forest pathologists might be similarly criticized, and need to develop a conceptual framework and the supporting analytical methods to characterize multiple disturbance pathosystems.

Relatively few analytic tools have been used to describe interacting assemblages of disturbances, although many studies have described parts of them. Knight (16) developed a qualitative model illustrating the interactions of diseases with other ecosystem elements, and suggested how these interactions related to flammability. Knight defined flammability as "the relative ease with which a substance ignites and sustains combustion." According to the Knight model, pathogens and other stress factors modify flammability by influencing fuel surface/volume and live-dead ratios, continuity of fuels, and porosity. Lundquist (17) quantified the co-occurring agents causing canopy gaps in ponderosa pine stands in the Black Hills by separating pairs of disturbances. A disadvantage of this approach is that it isolates pairs of factors from other factors that might influence the magnitude and nature of interactions. A covariate analysis method called path coefficient analysis was used by Desprez-Loustau and Wagner (5) to separate co-occurring factors influencing susceptibility of Pinus pinaster to Melampsora pinitorqua, the cause of pine twisting rust in Europe. Lundquist (18) used path coefficient analysis to quantify the relative importance of different canopy gap-causing disturbances occurring with Armillaria root disease in Black Hills ponderosa pine stands. Cooccurring disturbances interact in many ways and to several degrees of strength. Partitioning out which disturbance causes what effect to what degree in heterogeneous, long-lived forest systems can be very difficult. Path analysis offers a useful way of characterizing these interactions and of calculating the indirect effects of the major disturbances. These studies indicated that path analysis is a reasonable way to quantify impacts and partition among the assemblage of disturbance agents and other factors in multiple disturbance systems.

One of the advantages of using path analysis to partition relative importance in complex systems is its ability to estimate indirect effects (29). Indirect effects are defined as how one organism changes another's influence on a third (26). Cooccurring agents can affect the nature and magnitude of influence that another agent expresses. In the study described below, impact is defined as change in fuel loading, which is measured using various attributes of fuel. When the magnitude of disturbance activity changes, the magnitudes of various fuel characteristics change in concert, and the strength of this relationship can be measured with the correlation coefficient $r$. The correlation coefficient is actually influenced by several factors, and 
hence, $r=f$ (known factors + unknown factors). Path coefficient analysis quantitatively decomposes the components of $r$ associated with different interactions, and estimates the relative impact of each cause where different causes have direct influences resulting from acting alone, and each also has an indirect influence resulting from acting in combination with other causes (30).

A path diagram presents a structured hypothesis that is composed of arrows indicating potential interactions between components, path coefficients $\left(P_{i}\right)$, and correlation coefficients $\left(r_{i j}\right)$ (Fig. 1). A path coefficient is a standardized partial regression coefficient or beta weight, and is associated with each causal agent. It estimates the size of the direct effects of specific variables when other variables are held constant, similar to multiple regression. The correlation coefficients between agents correspond to extent to which agents are found together. Values above 0 mean that agents tend to be found together, and values below 0 mean they tend to be segregated. A value of 0 means there is no association between agents. Just as many causes can be built into this analysis, so can many effects of the action of those causes.

Path diagrams can present rather complex hypotheses. These diagrams represent a priori hypotheses based on experience, existing published and unpublished knowledge, and other subjective sources (28). A variety of path diagrams are commonly generated previous to the analysis, and the best one is selected based on goodness-offit statistics. Because plausible factors might be neglected, the best model is only the best of those tested. Lundquist (18) presents a relatively simple example of the calculations used for path analysis. Calculations for a two-disease system with two measured symptoms (Fig. 1) would be as follows (6):

Disease 1

Direct effect $1=\left(P_{1} * P_{3} * P_{4}\right)+\left(P_{1} * P_{3} * P_{5}\right)$ Indirect effect $1=\left[\left(P_{2} * P_{3} * P_{4}\right)+\left(P_{2} * P_{3} * P_{5}\right)\right]$ $* r_{1,2}$
Total effect $_{1}=$ direct effect $_{1}+$ indirect effect $_{1}$

Disease 2

Direct effect $2=\left(P_{2} * P_{3} * P_{4}\right)+\left(P_{2} * P_{3} * P_{5}\right)$

Indirect effect $_{2}=\left[\left(P_{1} * P_{3} * P_{4}\right)+\left(P_{1} * P_{3} * P_{5}\right)\right]$ $* r_{1,2}$

Total effect $_{2}=$ direct effect $_{2}+$ indirect effect $_{2}$

Tree diseases and other small-scale disturbances are key mortality factors influencing distribution and abundance of fuel loading in various forest types. These factors influence the small- and large-scale patterns of fuels and fire hazards. Although it is obvious that small-scale disturbances influence fuels, surprisingly little is known about the quantitative impacts of their activities at the landscape scale, especially when they co-occur with other disturbances. A fundamental understanding of these agents as they relate to fuel loading and wildfire hazard is essential for developing decision support systems that can help forest managers best mediate wildfire risk. The objective of this study was to estimate the relative importance in creating fuels of different diseases compared with each other and with other small-scale disturbances. In this study, we apply path analysis to quantify the relative importance of diseases and other disturbances in creating fuels in the Black Hills National Forest in South Dakota.

\section{MATERIALS AND METHODS}

Study site. This study was conducted in the Black Hills National Forest in west central South Dakota, USA. The Black Hills is the easternmost outlier of the Rocky Mountains. Elevation reaches 2,300 m (9). Forests occur between 1,200 and 2,100 $\mathrm{m}$. Precipitation averages about $750 \mathrm{~mm}$ per year, mostly as rain during summer months. Pinus ponderosa Douglas ex P. Laws is the dominant tree species. Other major tree species include Picea glauca (Moench) Voss, Populus tremuloides Michx., and Quercus macrocarpa Michx. (13).

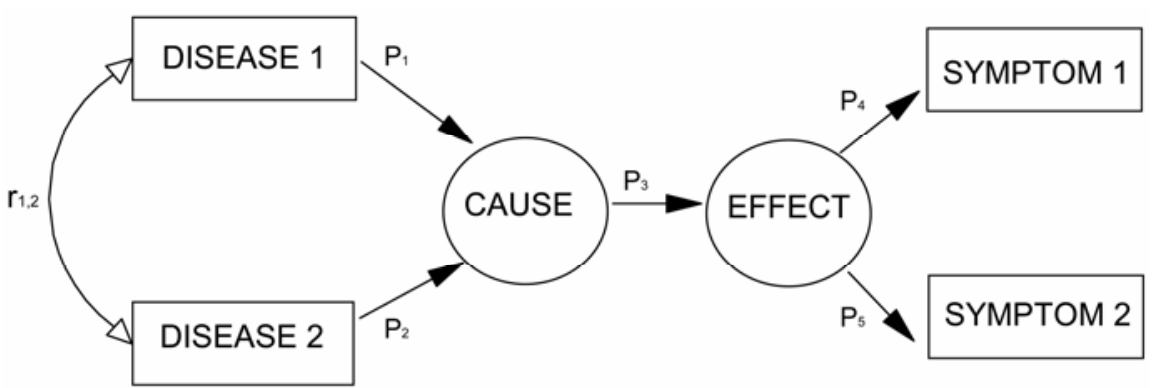

Fig. 1. Example of a path diagram showing a hypothetical situation in which DISEASE 1 and DISEASE 2 combine to represent a nonmeasurable factor called CAUSE. SYMPTOM 1 and SYMPTOM 2 combine to represent the factor called EFFECT. Straight lines are path coefficients $\left(P_{i}\right)$, which are measures of direct effect. Curved lines are measures of Pearson's $\Phi\left(r_{i j}\right)$ among different pairs of disturbances and are measures of the magnitude and direction of pair-wise relationships between diseases. Path coefficients and correlations between pairs of disturbances are related to the correlation coefficient between EFFECT and each disturbance.
Sample plots. A total of $15630 \times 30 \mathrm{~m}$ sample plots were randomly placed within the boundary of the Black Hills National Forest using a stratified design and methods described by Reich et al. (24). The forest was partitioned into pine, spruce, oak, aspen, and meadow vegetation classes. Variability within each partition was determined using an initial sample of 50 plots. Remaining plots were allocated to a stratum proportional to the variability in forest structure and fuel loading. Plots were oriented in a north-south direction and georeferenced with the aid of GPS. A 42-m transect was established diagonally across the sample plots from the southwest corner to the northeast corner. Three 1-mlong transects were established 7, 21, and $35 \mathrm{~m}$ along the 42-m transect.

Estimation of fuel loading. A planar intersect transect was used to estimate fuel loadings in metric tons/ha for the following size classes: $<0.6 \mathrm{~cm} ; 0.6$ to $2.5 \mathrm{~cm}$; and $>2.5 \mathrm{~cm}$ sound and dead (2). Fuel loadings in size classes under $7.6 \mathrm{~cm}$ were estimated by counting the number of intercepts on the three 1-m transects by species group (pine, spruce, aspen hardwood). Fuel loadings for woody material greater than $7.6 \mathrm{~cm}$ were estimated by measuring the diameter of all intercepts on the 42-m transect, by species group. In addition to the intercept data, information was collected on the depth $(\mathrm{cm})$ of the litter and duff on the three 1-m transects, along with estimates of the height of the woody fuels (cm) above the forest floor. All fuel loading estimates were adjusted for slope.

Diagnosis of disturbances. Presence and identity of any disturbance agent capable of killing parts or whole trees present in each plot were noted. Presence or absence of the following disturbances (or conditions) were noted: tree cutting, lightning damage, root rots, bark beetles, wind damage, fire, ice and snow damage, absent regeneration, shallow soil, suppression, stem rots, stem cankers, human-caused damage not tree cutting, and competition. The presence of natural meadows was also noted since tree establishment is lacking and processes occurring in these areas prevent or restrict trees from becoming established.

Because this list was based on previous disturbance surveys (17-19) and other studies in the study area, it is unlikely that any major disturbances were omitted. Nonetheless, other factors such as nutrient deficiencies, topographical features, disturbance symptoms from previous episodes, and other factors that directly or indirectly contribute to fuel loads might have been missed. Diagnosis of causal agents was based on a careful evaluation of obvious symptoms and signs and on a familiarity of the various disturbances occurring in the Black Hills based on earlier studies. For example, strong winds were commonly associated with uprooting 
and stem breakage. Ice and snow commonly caused trees with slender stems to bend, especially trees at the edges of existing canopy openings. Lightning often caused bark to strip up to many centimeters wide on the stem. Blackened stems and/or duff signified wildfire. Bark beetles caused discoloration of foliage and mortality of branches or main stems associated with egg galleries and frass under the bark. Root diseases caused a general progressive crown decline, with red or chlorotic needles, basal resinosis, stunted internodes and needles, and sometimes a limited cone crop. Stem cankers caused discolored and necrotic portions of stems and branches and flagging and spiketops in crowns. Human activity other than timber harvesting commonly involved road building and other clearing in the forest. Stem fall occurred when dominant trees fell on and toppled codominant neighboring trees. Symptoms commonly varied continuously in appearance and intensity due to tree age, host species, and environment. Best guesses were recorded when disturbance agents were not obvious. When more than one disturbance agent occurred, both were noted as causes. Diagnostic keys and published descriptions were used for difficult diagnoses (e.g., various forest insect and disease leaflets published by the USDA Forest Service online). Where causes could not be determined, disturbance agents were noted as unknown.
Generation and selection of a path model. Structural models were built and data analyzed using methods described above and in Lundquist (18). To meet the requirements for hypothesis testing, various models were proposed before analysis. These models were developed based on logic and published and unpublished knowledge of the various disturbances, as described by Mitchell (22). In all models, average fuel height, average depth of duff layer, average depth of litter layer, abundance of $<0.6 \mathrm{~cm}$ fuels, of fuels between 0.6 and $2.5 \mathrm{~cm}$, and of fuels $>2.5 \mathrm{~cm}$ were treated as indicators of the latent dependent variable, FUEL LOAD (Fig. 2). The models tested were:

Model 1: All disturbances were treated as indicators of the explanatory latent variable DISTURBANCE, and all disturbances interacted.

Model 2: All disturbances except lightning and shallow soil were treated as indicators of the latent variable DISTURBANCE. All diseases interacted.

Model 3: All disturbances except lightning, regeneration, and shallow soil were indicators of DISTURBANCE. Canopy cover and vegetation type were indicators of a second explanatory variable VEGETATION. Fuel load was dependent on both DISTURBANCE and VEGETATION.
All disturbances interacted. Canopy cover and vegetation type interacted.

Model 4: Tree cutting, root rots, bark beetles, wind damage, fire, ice and snow damage, stem rot, stem canker, human-caused damage, and tree cutting were indicator variables of DISTURBANCE. Canopy cover, vegetation type, suppression, competition, and meadow were indicators of VEGETATION. DISTURBANCE and VEGETATION were both explanatory variables for fuel load.

A $t$ test (25) was used to assess the significance of each path. Resulting $t$ values were approximately distributed according to a $t$ distribution. A critical value of 2.17 ( $P=0.05 ; \mathrm{df}=12$; two-tailed test $)$ was used to select significant correlations.

Calculation of direct and indirect effects. Akaike's Information Criterion (AIC) was used to assess fit of each model (1). Where AIC values differed less than 2.0, model averaging was used to determine weights, as described by Burnham and Anderson (3). The model with the lowest AIC was used to calculate direct, indirect, and total effects for each of the fuel generating disturbances, as described above. Effects of each disturbance were calculated using path coefficients $\left(P_{i}\right)$ generated with the RAMONA path analysis module of SYSTAT (SPSS Inc., Chicago). Data in the form of presence/absence were

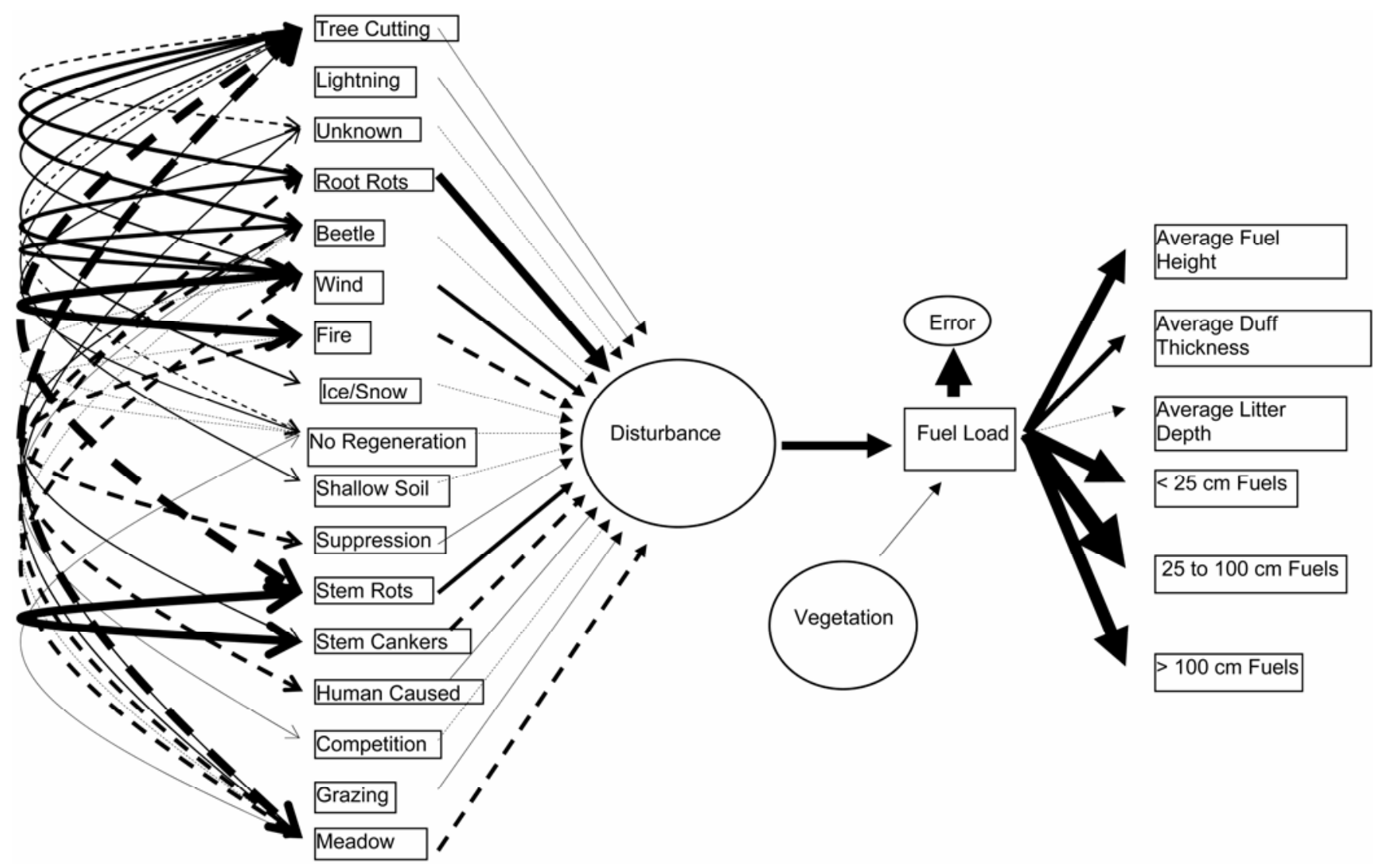

Fig. 2. Path diagram depicting significant interactions of various fuel influencing small-scale disturbances in the Black Hills of South Dakota. Solid lines represent positive effects and dashed lines represent negative effects. Line width indicates strength of interaction. 
used to calculate the Pearson's Phi correlation coefficient $(\Phi)$ matrix between disturbances, which was used as data input for the RAMONA analysis. Direct effects were calculated by multiplying path coefficients for every connecting arrow between a disturbance and the FUEL LOAD indicators, and indirect effects were calculated by multiplying the correlation coefficients and path coefficients for every connecting disturbance shown in the model and adding these values, as described above. Total effect was calculated by adding the sums for direct and indirect effects (5).

\section{RESULTS}

Averages for all plots combined were: fuel height $=6.57 \mathrm{~cm}$; duff height $=2.71$ $\mathrm{cm}$; litter depth $=3.49 \mathrm{~cm} ;<0.6 \mathrm{~cm}$ fuels $=$ 0.18 tons $/$ ha; 0.6 to $2.5 \mathrm{~cm}$ fuels $=2.10$ tons $/ \mathrm{ha}$; and $>2.5 \mathrm{~cm}$ fuels $=7.01$ tons $/$ ha (Table 1). Number of different disturbances within a single plot ranged from 1 for 22 stands to 6 for 3 stands. The most frequent disturbances were tree cutting, strong winds, root rots, and small fires. Multiple concurrent disturbances were found in 133 plots. Where disturbances coincided, the most common pairs were wind and root rots ( 22 plots) and wind and fire (22 plots).

Since AIC values differed by less than 2.0 for all four models tested (Table 2), and these models had similar probabilities of being selected as the best model, parameters were averaged for all models and weighted on the basis of AIC (21). The path diagram presented all disturbances as measurable manifestations of a nonmeasurable factor called DISTURBANCE, and average fuel height, average duff thickness, average litter depth, $<0.6 \mathrm{~cm}$ fuels, 0.6 to $2.5 \mathrm{~cm}$ fuels, and $>2.5 \mathrm{~cm}$ fuels as measurable characteristics of the nonmeasurable factor FUEL LOAD. All indicators of FUEL LOAD had positive associations with that factor, except average litter depth, which was negatively correlated.

Tree cutting, root rots, wind, suppression, stem rots, and human-caused disturbances had positive associations with DISTURBANCE, and all other disturbance agents had negative associations. Only root rots had a significantly large $t$ value in all models (range $=2.75$ to 4.52 ), but wind, fire, stem rot, shallow soil, and cankers had relatively large, but insignificant, values. The path coefficient between DISTURBANCE and FUEL LOAD was 0.426 with a $t$ value of 7.24 . The path coefficient between VEGETATION and FUEL LOAD was 0.21 with a $t$ value of 5.4. Average error estimate was 0.67 .

Pearson's Phi values for all pairs of disturbances and/or conditions are shown in Table 3. Significant correlations were found with all disturbances, but correlations for most pairs were either so small that they were biologically irrelevant or they were statistically insignificant (Fig. 2 ). The most diverse interactions occurred with tree cutting, meadows, strong wind, bark beetles, and failed regeneration.

Negative correlations indicated that different disturbances or conditions tended to not co-occur. Significant negative correlations were observed between tree cutting and unknown causes, failed regeneration, and stem rots; between meadows and tree cutting, root rots, bark beetles, and strong wind; between strong wind and no regeneration; between bark beetles and cankers and human causes; and between fire and failed regeneration and suppression. Posi-

Table 1. Number of stands in which various causes of fuel loading were found

\begin{tabular}{|c|c|c|c|c|c|c|c|c|}
\hline Cause & $\begin{array}{l}\text { No. of } \\
\text { stands }\end{array}$ & $\begin{array}{l}\text { Fuel height } \\
\text { (cm) }\end{array}$ & $\begin{array}{l}\text { Duff height } \\
\text { (cm) }\end{array}$ & $\begin{array}{l}\text { Litter depth } \\
\text { (cm) }\end{array}$ & $\begin{array}{c}<0.6 \mathrm{~cm} \text { fuels } \\
(\mathrm{t} / \mathrm{ha})\end{array}$ & $\begin{array}{l}0.6-2.5 \mathrm{~cm} \\
\text { fuels }(\mathrm{t} / \mathrm{ha})\end{array}$ & $\underset{(\mathrm{t} / \mathrm{ha})}{>2.5 \mathrm{~cm} \text { fuels }}$ & $\begin{array}{c}\text { Path } \\
\text { coefficient }\end{array}$ \\
\hline Cutting & 68 & 6.83 & 2.41 & 3.81 & 0.14 & 1.68 & 7.50 & 0.060 \\
\hline Lightning & 2 & 8.69 & 3.81 & 3.81 & 0.05 & 1.78 & 8.85 & -0.001 \\
\hline Unknown & 7 & 4.32 & 3.12 & 3.23 & 0.11 & 1.47 & 6.20 & -0.001 \\
\hline Root rot & 45 & 5.66 & 2.67 & 3.40 & 0.17 & 1.99 & 6.36 & 0.597 \\
\hline Bark beetles & 31 & 6.68 & 2.74 & 3.25 & 0.21 & 2.26 & 6.91 & -0.039 \\
\hline Strong wind & 46 & 5.56 & 2.64 & 3.45 & 0.17 & 1.96 & 6.29 & 0.366 \\
\hline Fire & 36 & 6.32 & 2.59 & 3.28 & 0.20 & 2.18 & 7.05 & -0.302 \\
\hline Ice/snow & 20 & 7.09 & 2.90 & 3.23 & 0.21 & 2.49 & 8.62 & -0.094 \\
\hline No regeneration & 13 & 7.34 & 2.92 & 3.91 & 0.17 & 1.81 & 4.20 & -0.067 \\
\hline Shallow soil & 15 & 8.36 & 2.77 & 3.66 & 0.20 & 2.52 & 6.66 & -0.063 \\
\hline Suppression & 19 & 7.39 & 2.77 & 3.40 & 0.19 & 2.55 & 8.00 & 0.128 \\
\hline Stem rot & 24 & 6.58 & 2.84 & 3.28 & 0.21 & 2.63 & 8.30 & 0.307 \\
\hline Canker & 19 & 7.39 & 2.77 & 3.40 & 0.19 & 2.55 & 8.00 & -0.245 \\
\hline Human & 16 & 8.08 & 2.84 & 3.58 & 0.19 & 2.39 & 7.29 & 0.088 \\
\hline Competition & 7 & 4.32 & 3.12 & 3.23 & 0.11 & 1.47 & 6.20 & -0.025 \\
\hline Grazing & 2 & 8.69 & 3.81 & 3.81 & 0.05 & 1.78 & 8.85 & 0.016 \\
\hline Meadow & 12 & 6.15 & 3.00 & 3.89 & 0.18 & 1.96 & 4.55 & -0.213 \\
\hline
\end{tabular}

Table 2. Average Pearson Phi values weighted for each model on the basis of relative Akaike's Information Criterion (AIC) value for various combinations of disturbance causes

\begin{tabular}{|c|c|c|c|c|c|c|c|c|c|c|c|c|c|c|c|c|}
\hline Interactions & $\begin{array}{l}\text { Cut- } \\
\text { ting }\end{array}$ & $\begin{array}{c}\text { Light- } \\
\text { ning }\end{array}$ & $\begin{array}{c}\text { Un- } \\
\text { known }\end{array}$ & $\begin{array}{c}\text { Root } \\
\text { rot }\end{array}$ & Beetles & Wind & Fire & Ice & $\begin{array}{l}\text { Regen- } \\
\text { eration }\end{array}$ & Soil & $\begin{array}{c}\text { Sup- } \\
\text { pres- } \\
\text { sion }\end{array}$ & $\begin{array}{c}\text { Stem } \\
\text { rot }\end{array}$ & $\begin{array}{l}\text { Can- } \\
\text { ker }\end{array}$ & Human & $\begin{array}{l}\text { Com- } \\
\text { peti- } \\
\text { tion }\end{array}$ & $\begin{array}{c}\text { Graz- } \\
\text { ing }\end{array}$ \\
\hline Lightning & 0.00 & & & & & & & & & & & & & & & \\
\hline Unknown & -0.05 & -0.01 & & & & & & & & & & & & & & \\
\hline Root rot & 0.14 & -0.02 & -0.03 & & & & & & & & & & & & & \\
\hline Bark beetles & 0.32 & 0.02 & -0.02 & 0.29 & & & & & & & & & & & & \\
\hline Strong wind & 0.16 & 0.03 & -0.03 & 0.37 & 0.34 & & & & & & & & & & & \\
\hline Fire & 0.17 & 0.01 & -0.03 & 0.18 & 0.18 & 0.56 & & & & & & & & & & \\
\hline Ice/snow & 0.07 & -0.01 & -0.02 & 0.03 & 0.04 & -0.05 & 0.06 & & & & & & & & & \\
\hline No regeneration & -0.06 & -0.01 & 0.14 & -0.03 & -0.04 & -0.05 & -0.04 & -0.03 & & & & & & & & \\
\hline Shallow soil & 0.01 & 0.03 & -0.02 & -0.02 & 0.03 & 0.01 & 0.01 & 0.02 & 0.01 & & & & & & & \\
\hline Suppression & -0.20 & -0.01 & -0.02 & -0.01 & -0.09 & -0.15 & -0.27 & 0.19 & -0.03 & -0.01 & & & & & & \\
\hline Stem rot & -0.43 & -0.01 & -0.02 & 0.14 & 0.04 & 0.26 & -0.02 & 0.04 & -0.02 & -0.01 & -0.02 & & & & & \\
\hline Canker & -0.10 & -0.01 & -0.02 & -0.16 & -0.27 & -0.03 & -0.08 & 0.02 & -0.03 & -0.03 & 0.03 & 0.42 & & & & \\
\hline Human & -0.29 & -0.01 & -0.02 & -0.17 & -0.32 & -0.11 & -0.10 & -0.03 & -0.01 & -0.03 & -0.02 & -0.17 & -0.13 & & & \\
\hline Competition & 0.05 & -0.01 & -0.01 & -0.13 & 0.16 & 0.07 & 0.02 & 0.00 & 0.01 & 0.01 & -0.13 & 0.22 & 0.00 & 0.03 & & \\
\hline Grazing & 0.02 & 0.00 & -0.01 & -0.02 & -0.01 & 0.01 & 0.01 & -0.01 & -0.01 & -0.01 & -0.01 & -0.01 & 0.03 & -0.01 & -0.01 & \\
\hline Meadow & -0.43 & -0.01 & 0.13 & -0.30 & -0.23 & -0.31 & -0.26 & -0.18 & 0.12 & -0.02 & -0.17 & -0.20 & -0.17 & -0.04 & -0.10 & 0.01 \\
\hline
\end{tabular}


tive correlations indicated that disturbances or conditions tended to occur together. Significant positive correlations were observed between tree cutting and lightning, root rots, bark beetles, strong wind, ice and snow damage, shallow soils, and human causes; between meadows and unknown causes and failed regeneration; between strong wind and root rots, bark beetles, and fire; between unknown causes and failed regeneration; and between stem rot and cankers.

Disturbance agents varied in total effect on fuel loads (Table 4). The path model predicted that root rot had the largest total effect followed (in order of importance) by strong wind, stem rot, suppression, human disturbances, tree cutting, and grazing. These agents all caused increases in fuel loads. In contrast, meadows, stem cankers, fires, ice and snow damage, failed regeneration, shallow soil, competition, and bark beetles were all associated with less severe fuel loads. Fire and wind had the largest indirect effects and root rot had the largest direct effects.

\section{DISCUSSION}

Wildfires change forest landscapes in ways that often influence the occurrence, distribution, and epidemiology of forest diseases, insect pests, and other smallscale disturbances $(7,10-12)$. These disturbances, in turn, can change forest conditions to increase or decrease risk and hazard of wildfires. This reciprocal relationship is well-recognized, but has not been well-studied, primarily because quantitative tools to characterize such interactions are lacking.

Knight (16) presents a conceptual model of the various direct and indirect factors that influence flammability. In this model, in addition to the fuel complex, the plant species composition, wind drying, and fuel complex directly influence flammability. Different disturbance and recovery processes have different influences. Pathogens, for example, play mostly indirect roles. Pathogens alter plant species composition and stand structure, increasing or decreasing susceptibility to wind damage, which directly adds to the fuel complex. Our understanding of the interactions of the roles of different disturbances in ecological processes has expanded considerably since Knight first proposed this model.

Knight's model emphasizes the fact that forests are ecologically complex systems. Polis (23), however, suggests that only four attributes of these types of systems are really important to characterize:

1) Factors that most significantly impact system dynamics. Various fuel-generating disturbances occur in the Black Hills, but not all are important. Some cause fuels to accumulate and some cause fuels to decrease. Results of the present study suggest that the most important fuel-generating disturbance in the area studied is root rot.
The dominant root rot of ponderosa pine in the Black Hills is Armillaria root disease, caused by Armillaria ostoyae. Root diseases, like that caused by $A$. ostoyae, are commonly well-integrated as a factor of the site. As such, they commonly act continuously at relatively low levels, seldom dramatically, accumulating fuels. Because of their "background nature", they usually interact with whatever disturbance might share the same space at the same time.

2) The relative importance of the factors influencing the system. Path analysis was used in the present study to estimate relative importance. The analysis indicated that the order of importance for the factors studied (from most to least) was: root rots, wind, stem rots, suppression, human disruptions, tree cutting, grazing, lightning, bark beetles, competition, shallow soil, ice and snow damage, fires, canker diseases, and processes occurring within natural meadows.

3) The nature of interactions among factors influencing the system. Results suggest that not all disturbances interact when they occur together, but that some might,

Table 3. Akaike's Information Criterion (AIC) and residual estimates associated with each of the four structural models tested in this study. Residual estimates refer to one endogenous variable, FUEL LOAD

\begin{tabular}{lccc}
\hline Model $^{\mathbf{a}}$ & AIC & Weight $^{\mathbf{b}}\left(\boldsymbol{w}_{\boldsymbol{i}}\right)$ & $\begin{array}{c}\text { Residual } \\
\text { estimate }\end{array}$ \\
\hline Model 1 & 3.50 & 0.20 & 0.777 \\
Model 2 & 2.21 & 0.38 & 0.819 \\
Model 3 & 3.48 & 0.20 & 0.732 \\
Model 4 & 3.41 & 0.21 & 0.671 \\
\hline
\end{tabular}

${ }^{a}$ Model 1: All disturbances were treated as indicators of explanatory latent variable DISTURBANCE, and all disturbances interacted. Model 2: All disturbances except lightning and shallow soil were treated as indicators of latent variable DISTURBANCE. All diseases interacted. Model 3: All disturbances except lightning, regeneration, shallow soil were indicators of DISTURBANCE. Canopy cover and vegetation type were indicators of a second explanatory variable, VEGETATION. Fuel load was dependent on both DISTURBANCE and VEGETATION. All disturbances interacted. Canopy cover and vegetation type interacted. Model 4: Tree cutting, roots rots, bark beetles, wind damage, fire, ice and snow damage, stem rot, stem canker, human-caused damage, tree cutting were indicator variables of DISTURBANCE. Canopy cover, vegetation type, suppression, competition, meadow were indicators of VEGETATION. DISTURBANCE and VEGETATION were both explanatory variables for fuel load.

$\mathrm{b}$ Weight $\left(w_{i}\right)=\mathrm{AIC}_{i} /\left(\mathrm{AIC}_{i}-\mathrm{AIC}_{\mathrm{Min}}\right)$.

Table 4. Estimates of direct and indirect effects of different small-scale disturbances on fuel loading in forest stands in the Black Hills, South Dakota

\begin{tabular}{lccc}
\hline Cause & Direct effects & Indirect effects & Total effects \\
\hline Root rot & 0.254 & 0.015 & 0.269 \\
Strong wind & 0.156 & 0.064 & 0.220 \\
Stem rot & 0.131 & 0.027 & 0.158 \\
Suppression & 0.055 & 0.019 & 0.074 \\
Human & 0.037 & 0.003 & 0.040 \\
Cutting & 0.026 & -0.009 & 0.016 \\
Grazing & 0.007 & 0.000 & 0.007 \\
Lightning & 0.000 & 0.000 & 0.000 \\
Unknown & 0.000 & -0.001 & -0.002 \\
Bark beetles & -0.017 & 0.005 & -0.011 \\
Competition & -0.011 & 0.000 & -0.011 \\
Shallow soil & -0.027 & 0.000 & -0.027 \\
No regeneration & -0.029 & -0.007 & -0.036 \\
Ice/snow & -0.040 & 0.000 & -0.040 \\
Fire & -0.129 & 0.068 & -0.061 \\
Canker & -0.104 & 0.035 & -0.070 \\
Meadow & -0.091 & -0.072 & -0.163 \\
\hline
\end{tabular}


host species, and show other characteristics that make them complex ecological and economic phenomena. It is difficult to standardize among specific disturbances and the fuels they generate. Since expression of influence is relative, assessment depends on the variables used to characterize impact. In this study, measured variables included fuel height, duff depth, litter depth, and amounts of various fuel types. These variables were incorporated into a single response variable, FUEL LOAD, in the path analysis. Individual variables did not equally contribute to FUEL LOAD, but all fuel loading measures and average fuel height had relatively large inputs into this factor. The high residual associated with FUEL LOAD suggests that not all key factors were included in the analysis that key factors exhibit nonlinear effects not picked up by the models, or both, and that much remains unexplained about the causes of the fuel loads assessed. VEGETATION, for instance, was at least as dominating a cause of fuels as DISTURBANCES. Furthermore, other variables not used in this analysis, like stem density, age, previous history of infection, soil properties, and various other factors and their cumulative impact over time affect various fuel load properties.

The results of this study apply to the Black Hills, which is in many ways unique. Studies elsewhere using the same methods suggest that the cause/effect associations probably differ by location. Similarly, it is well-known that fire regimes vary across regions (20).

\section{CONCLUSION}

The ecological and economic impacts of individual disturbances on forest stands are often difficult to determine because of the difficulty in accounting for indirect impacts arising from their interactions with other agents. In practice, impacts are usually attributed to the most obvious disease, which might not always be the dominant or most damaging. Root diseases, for example, are commonly so well integrated with other factors of their environment that they are probably better described by their associations with these factors, especially under endemic conditions. More knowledge about interactions of different disturbances would enable more realistic and more accurate assessments of these processes in forests, better predictions of eco- nomic impacts, greater understanding of the underlying ecological processes, and development of better management practices.

\section{ACKNOWLEDGMENTS}

I thank Rudy King for his statistical review of this manuscript and Bob Hamre for his editorial review.

\section{LITERATURE CITED}

1. Akaike, H. 1973. Information theory and an extension of the maximum likelihood principle. Pages 267-281 in: Second International Symposium on Information Theory. B. N. Petran and R. Csaaki, eds. Akadeemiai Kiado, Budapest, Hungary.

2. Brown, J. K., Oberheu, R. D., and Johnston, C. M. 1982. Handbook for Inventorying Surface Fuels and Biomass in the Interior West. U.S. Dep. Agric. For. Serv., Intermountain Forest and Range Experiment Station, General Technical Report INT-129.

3. Burnham, K. P., and Anderson, D. R. 2002. Model Selection and Multimodel Inference - A Practical Information - Theoretical Approach, 2nd ed. Springer-Verlag, New York.

4. Culver, D. C. 1981. Introduction to the theory of species interactions. Pages 229-241 in: The Fungal Community. D. T. Wicklow and G. C. Carroll, eds. Marcel Dekker, New York.

5. Desprez-Loustau, M. L., and Wagner, K. 1997. Components of maritime pine susceptibility to twisting rust - A path coefficient analysis. Eur. J. Plant Pathol. 103:653-665.

6. Dewey, D. R., and Lu, K. H. 1959. A correlation and path-coefficient anlaysis of components of crested wheatgrass seed production. Agron. J. 51:515-518.

7. Dickman, A., and Cook, S. 1989. Fire and fungus in a mountain hemlock forest. Can. J. Bot. 67:2005-2016.

8. Duffy, J. E. 2002. Biodiversity and ecosystem function: The consumer connection. OIKOS 99:201-219.

9. Froiland, S. G. 1990. Natural history of the Black Hills and Badlands. The Center of Western Studies, Augustana College, Sioux Falls, SD.

10. Gara, R. I., Littke, W. R., Agee, J. K., Geiszler, D. R., Stuart, J. D., and Driver, C. H. 1985. Influence of fires, fungi, and mountain pine beetles on development of a lodgepole pine forest in south-central Oregon. Pages 153-162 in: Lodgepole Pine: The Species and Its Management. D. M. Baumgartner, R. G. Krebill, J. T. Arnott, and G. F. Weetman, eds. Washington State University Cooperative Extension Service, Pullman, WA.

11. Hansen, E. M., and Goheen, D. J. 1989. Root disease complexes in the Pacific Northwest. Pages 129-141 in: D.J. Morrison, ed. Proc. IUFRO Int. Conf. Root Butt Rots, 7th. August 9-16, 1988, Vernon and Victoria, British Columbia.

12. Hansen, E. M., and Goheen, E. M. 2000. Phellinus weirii and other native root pathogens as determinants of forest structure and process in western North America. Annu. Rev.
Phytopathol. 38:515-539.

13. Hoffman, G. R., and Alexander, R. R. 1987. Forest vegetation of the Black Hills National Forest of South Dakota and Wyoming: A habitat type classification. U.S. Dep. Agric. For. Serv., Rocky Mountain Forest and Range Experiment Station Research Paper RM-276.

14. Kareiva, P., and Wennergren, U. 1995. Connecting landscape patterns to ecosystem and population processes. Nature 373:299-302.

15. Keane, R. E., Burgan, R., and van Wagtendonk, J. 2001. Mapping wildland fuels for fire management across multiple scales: Integrating remote sensing, GIS, and biophysical modeling. Int. J. Wildland Fire 10:301-319.

16. Knight, D. H. 1987. Parasites, lightning, and the vegetation mosaic in wilderness landscapes. Pages 59-83 in: Landscape Heterogeneity and Disturbance. M. G. Turner, ed. Springer-Verlag, New York.

17. Lundquist, J. E. 1995. Pest interactions and canopy gaps in ponderosa pine in the Black Hills, South Dakota, USA. For. Ecol. Manag. 74:49-59.

18. Lundquist, J. E. 2000. A method of estimating direct and indirect effects of Armillaria root disease and other small-scale forest disturbances on canopy gap size. For. Sci. 46(3):356-362.

19. Lundquist, J. E., and Negron, J. F. 2000. Endemic forest disturbances and stand structure of ponderosa pine in the Upper Pine Creek Research Natural Area, South Dakota. Natural Areas J. 20:126-132.

20. Malamud, B. D., Millington, J. D. A., and Perry, G. L. W. 2005. Characterizing wildfire regimes in the United States. Proc. Nat. Acad. Sci. USA. 102:4694-4699.

21. McIntire, E. J. B. 2004. Understanding natural disturbance boundary formation using spatial data and path analysis. Ecology 85(7):19331943.

22. Mitchell, R. J. 1993. Path analysis: Pollination. Pages 212-231 in: Design and Analysis of Ecological Experiments. S. M. Scheiner and J. Gurevitch, eds. Chapman \& Hill, New York.

23. Polis, G. A. 1994. Food webs, trophic cascades and community structure. Aust. J. Ecol. 19:121-136.

24. Reich, R. M., Lundquist, J. E., and Bravo, V. A. 2004. Spatial models for estimating fuel loads in the Black Hills, South Dakota, USA Int. J. Wildland Fire 13:119-129.

25. Sokal, R. R., and Rohlf, F. J. 1981. Biometry. W.H. Freeman and Co., New York

26. Strauss, S. Y. 1991. Indirect effects in community ecology: Their definition, study and importance. TREE 6(7):206-210.

27. Tilman, D. 1999. the ecological consequences of changes in biodiversity: A search for general principles. Ecology 80:1455-1474.

28. Wilkinson, L., Blank, G., and Gruber, C. 1996. Desktop Data Analysis with SYSTAT. Prentice-Hall, Upper Saddle River, NJ.

29. Wootton, J. T. 1994. The nature and consequences of indirect effects in ecological communities. Annu. Rev. Ecol. Syst. 25:443-466.

30. Wright, S. 1921. Correlation and causation. J. Agric. Res. 20:557-585. 